\title{
ECMO use in COVID-19: lessons from past respiratory virus outbreaks - a narrative review
}

\author{
Hwa Jin Cho ${ }^{1,2^{*}+}$ D , Silver Heinsar ${ }^{1 \dagger}$, In Seok Jeong ${ }^{3}$, Kiran Shekar ${ }^{1,4}$, Gianluigi Li Bassi ${ }^{1,5}$, Jae Seung Jung ${ }^{1,6}$,
} Jacky Y. Suen ${ }^{1}$ and John F. Fraser ${ }^{1,4}$

\begin{abstract}
The spread of coronavirus disease 2019 (COVID-19) continues to grow exponentially in most countries, posing an unprecedented burden on the healthcare sector and the world economy. Previous respiratory virus outbreaks, such as severe acute respiratory syndrome (SARS), pandemic H1N1 and Middle East respiratory syndrome (MERS), have provided significant insights into preparation and provision of intensive care support including extracorporeal membrane oxygenation (ECMO). Many patients have already been supported with ECMO during the current COVID-19 pandemic, and it is likely that many more may receive ECMO support, although, at this point, the role of ECMO in COVID-19-related cardiopulmonary failure is unclear. Here, we review the experience with the use of ECMO in the past respiratory virus outbreaks and discuss potential role for ECMO in COVID-19.
\end{abstract}

Keywords: Coronavirus disease-2019 (COVID-19), Extracorporeal membrane oxygenation (ECMO), Severe acute respiratory syndrome (SARS), Pandemic H1N1, Middle East respiratory syndrome (MERS)

\section{Background}

On December 2019, the district of Wuhan in central China announced detection of a previously undescribed virus that led to clusters of pneumonia. The disease caused by this novel severe acute respiratory syndrome coronavirus 2 (SARS-CoV-2) was subsequently named coronavirus disease 2019, the COVID-19. The SARSCoV-2 outbreak was declared as a public health emergency of international concern by the World Health Organization (WHO) on 30 January and a pandemic on 11 March [1]. Despite lessons learnt from previous outbreaks, the preparedness and awareness for such a

\footnotetext{
* Correspondence: chhj98@gmail.com

${ }^{+} \mathrm{H}$ wa Jin Cho and Silver Heinsar contributed equally to this work as the first authors.

${ }^{1}$ Critical Care Research Group, Faculty of Medicine, University of Queensland and The Prince Charles Hospital, Brisbane, Australia

${ }^{2}$ Department of Pediatrics, Chonnam National University Children's Hospital and Medical School, Gwangju, Republic of Korea

Full list of author information is available at the end of the article
}

transmittable virus was inadequate to stop its spread of COVID-19 to over 4,700,000 patients with crude mortality of $6.6 \%$ as of May 192020 [2]. The mortality in mechanically ventilated COVID-19 patients remains high, and it is unclear if some of these patients may be rescued with ECMO.

There have been several viral outbreaks in recent memory, including severe acute respiratory syndrome (SARS), pandemic H1N1 influenza and the Middle East respiratory syndrome (MERS) (Fig. 1). Whilst the SARS outbreak in China in 2002 [3] caused an outbreak of severe acute respiratory syndrome through coronavirus (SARS-CoV) [4-8], there is minimal reported data on the use of ECMO. This was because ECMO was not commonly used at that time, even in those critically ill patients who did not respond favourably to conventional mechanical ventilation and other adjuncts [9]. There is some data on use of ECMO in MERS [10-15]. The 2009 H1N1 pandemic witnessed the rise of ECMO, and this 

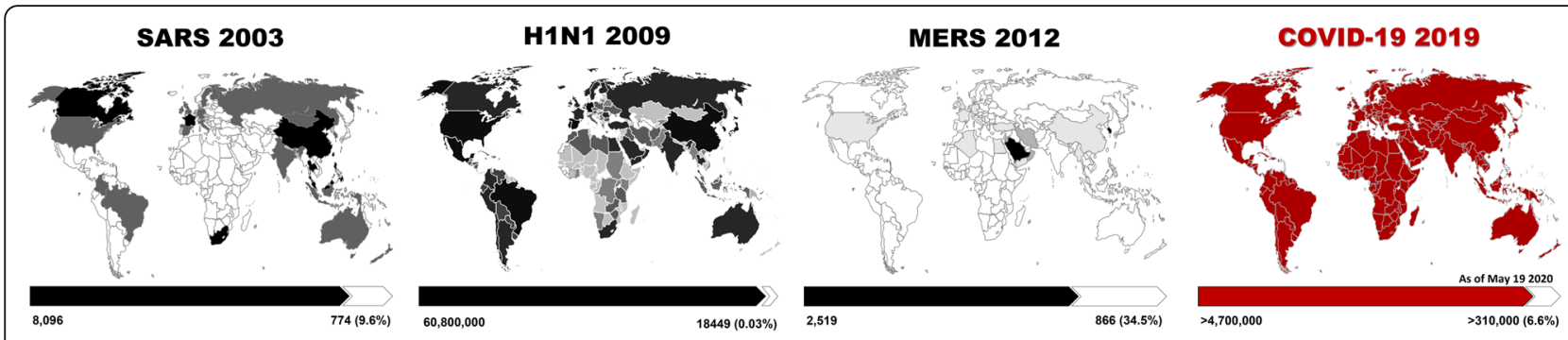

Fig. 1 Geographical distribution in previous viral outbreaks with the name of viral outbreaks and onset year. The number of infected cases (coloured bar) and number of deaths (blank bar) with percentage of death are described under each map. The length of the bars represent the approximate ratio of infected cases to deaths. The geographic distribution in COVID-19 is not expressed in this figure since the numbers and countries are still changing. As of May 19, 2020, total infected numbers of cases are over 4,700,000 and over 310,000 (6.6\%) died of COVID-19. SARS Severe acute respiratory syndrome; MERS Middle East respiratory syndrome; COVID-19 Coronavirus disease 2019

in part can be attributed to the significant "age shift" with younger patients ( $<65$ years of age) getting more affected by the virus. Improvements in technology over time have certainly played a significant role too.

Since the 2009 H1N1 pandemic, more evidence has emerged support venovenous $(\mathrm{V}-\mathrm{V})$ ECMO use in ARDS [16-20]. The use of venoarterial (V-A) ECMO for cardiac support is an evolving area and certainly needs further evidence. Although ECMO has a role in selected patients in context of the current pandemic, the criteria for patient selection and timing of ECMO initiation are yet to be defined. This is important to allow judicious use of available resources such resource-consumptive circumstances [21]. In this narrative review, the focus will be on the use of ECMO during previous viral outbreak as well as in COVID-19 to learn lessons regarding guidance of treatment that will benefit all of healthcare workers and patients.

\section{Cardiopulmonary complications in viral outbreaks} Whilst significant pulmonary pathology is the hallmark of recent viral outbreaks which was respiratory, the incidence of significant injuries to cardiovascular system has also been reported.

Both H1N1 and MERS were associated with significant cardiopulmonary involvement. Although severe pneumonia and ARDS were mostly commonly seen complications, Dawood et al. conducted calculations of crude respiratory and cardiovascular mortality rates from H1N1, estimating the total attributable deaths at 200,000 and 80,000 , respectively [22]. Fulminant myocarditis was reported during the H1N1 pandemic [23]; acute myocarditis, acute myocardial infarction, acute heart failure, pericarditis and shock were also reported in patients with MERS [13, 24-26].

In COVID-19, whilst most commonly reported pulmonary complications in critically ill patients were also pneumonia and ARDS [27-30], there are substantial concerns regarding micro- and macro-vascular complications, perhaps relating to intravascular thromboses or endothelial dysfunctions [31, 32]. Regarding cardiovascular complications, acute cardiac injury (7 17\%), shock (8-7\%), septic shock (20\%), arrhythmia (16.7\%) and heart failure (23\%) were reported in hospitalised patients [27-30]. There are few case reports of myopericarditis with cardiac tamponade and pericardial effusion [33, 34]. Ruan et al. reported up to $7 \%$ of patients die of fulminant myocarditis and this may be a contributing factor in up to $33 \%$ of deaths [35].

Thus, the respiratory viral outbreaks may lead to significant cardiopulmonary failure that is refractory to conventional medical management. During a pandemic, carefully selected patients may be rescued with ECMO, as it warrants excess amounts of limited assetspersonnel. Recently published Extracorporeal Life Support Organization (ELSO) COVID-19 guidelines provide recommendations for ECMO use in this setting [36]. The reported complications in COVID-19 are described in Table 1.

\section{ECMO use in recent viral outbreaks H1N1}

The spring of 2009 in Mexico saw the nascence of the first pandemic of the twenty-first century, the influenza A, H1N1 [37]. This H1N1 virus initially spread through North America, but eventually caused a global pandemic that lasted beyond the usual influenza season in the Northern Hemisphere [38, 39].

Eight studies that reported ECMO use during H1N1 are summarised in Table 2. H1N1-induced ARDS in 2009 resulted in the rapid uptake of ECMO use, and ECMO played an evolving role in critically ill patients $[40,48]$. Pham et al. have reported factors associated with death in 123 ECMO treated patients for H1N1induced ARDS [45]. They concluded that ECMO initiation facilitated the use of ultra-protective ventilation 
Table 1 Reported complications with COVID-19

\begin{tabular}{|c|c|c|c|c|c|}
\hline & $\begin{array}{l}\text { Total number } \\
\text { of patients }\end{array}$ & $\begin{array}{l}\text { Venovenous } \\
\text { ECMO \% }\end{array}$ & $\begin{array}{l}\text { Pulmonary } \\
\text { complications }\end{array}$ & $\begin{array}{l}\text { Cardiovascular } \\
\text { complications }\end{array}$ & Other complications \\
\hline Huang C [27] & 41 hospitalised & NA & ARDS (29\%) & $\begin{array}{l}\text { Acute cardiac injury }(12 \%)^{a} \\
\text { Shock }(7 \%)\end{array}$ & $\begin{array}{l}\text { AKI (7\%) } \\
\text { Secondary infection (10\%) }\end{array}$ \\
\hline Wang D [28] & 138 hospitalised & NA & ARDS (19.6\%) & $\begin{array}{l}\text { Shock }(8.7 \%) \text {, Acute } \\
\text { cardiac injury }(7.2 \%), \\
\text { Arrhythmia }(16.7 \%)\end{array}$ & AKI (3.6\%) \\
\hline Yang X [29] & 52 ICU admitted & NA & $\begin{array}{l}\text { ARDS (67\%) } \\
\text { Hospital acquired } \\
\text { pneumonia }(11.5 \%) \\
\text { Pneumothorax (2\%) }\end{array}$ & Cardiac injury (23\%) & $\begin{array}{l}\text { AKI (29\%) } \\
\text { Liver dysfunction (29\%) } \\
\text { Hyperglycaemia (35\%) } \\
\text { Gl haemorrhage (4\%) } \\
\text { Bacteremia (2\%) } \\
\text { Urinary tract infection (2\%) }\end{array}$ \\
\hline Zhou F [30] & 191 hospitalised & NA & $\begin{array}{l}\text { Respiratory failure (54\%) } \\
\text { ARDS (31\%) }\end{array}$ & $\begin{array}{l}\text { Heart failure }(23 \%) \\
\text { Acute cardiac injury (17\%) } \\
\text { Septic shock (20\%) }\end{array}$ & $\begin{array}{l}\text { Sepsis (59\%) } \\
\text { Coagulopathy (19\%) } \\
\text { Acute kidney injury (15\%) } \\
\text { Secondary infection (15\%) } \\
\text { Hypoproteinemia (12\%) } \\
\text { Acidosis (9\%) }\end{array}$ \\
\hline Varga Z [32] & 3 cases & No ECMO & Respiratory failure (3) & $\begin{array}{l}\text { Endothelitis in organ } \\
\text { vessels (3) } \\
\text { Myocardial infarction (1) } \\
\text { Reduced LV EF and } \\
\text { circulatory collapse (1) }\end{array}$ & $\begin{array}{l}\text { Mesenteric ischemia (2) } \\
\text { Multiorgan failure (1) }\end{array}$ \\
\hline Xie Y [31] & 2 cases & No ECMO & Pulmonary embolism (2) & & \\
\hline Hua A [33] & 1 case & No ECMO & & $\begin{array}{l}\text { Myopericarditis (1) } \\
\text { Cardiac tamponade } \\
\text { Pericardial effusion }\end{array}$ & \\
\hline Inciardi RM [34] & 1 case & No ECMO & & $\begin{array}{l}\text { Myopericarditis with } \\
\text { systolic dysfunction (1) }\end{array}$ & \\
\hline
\end{tabular}

AKI acute kidney injury, ARDS acute respiratory distress syndrome, ECMO extracorporeal membrane oxygenation, $G I$ gastrointestinal, $N A$ not applicable ${ }^{a}$ Defined as blood levels of hypersensitive troponin I above the 99th percentile upper reference limit $(>28 \mathrm{pg} / \mathrm{mL}$ ) or new abnormalities shown on electrocardiography and echocardiography

Table 2 Demographic data, the patient characteristics and ECMO data of 8 multicentre studies with H1N1 outbreak (2009-2010)

\begin{tabular}{|c|c|c|c|c|c|c|c|}
\hline Study group & $\begin{array}{l}\text { Data collection/ } \\
\text { population }\end{array}$ & $\begin{array}{l}\text { ECMO pts./total } \\
\text { H1N1 pts. }\end{array}$ & $\begin{array}{l}\text { Age of ECMO } \\
\text { pts. (years) }\end{array}$ & $\begin{array}{l}\mathrm{PaO} 2 / \mathrm{FlO}_{2}^{\mathrm{a}} \\
(\mathrm{mmHg})\end{array}$ & $\begin{array}{l}\text { MV duration } \\
\text { (days) }\end{array}$ & $\begin{array}{l}\text { ECMO duration } \\
\text { (days) }\end{array}$ & $\begin{array}{l}\text { Discharged } \\
\text { alive }{ }^{\mathbf{b}}, \boldsymbol{n}(\%)\end{array}$ \\
\hline $\begin{array}{l}\text { ANZ ECMO Influenza } \\
\text { Investigator [40] }\end{array}$ & Retrospective/15 ICUs & $68 / 194$ & $34.4(26.6-43.1)$ & $56(48-63)$ & NA & $10(7-15)$ & $32(47.1 \%)$ \\
\hline UK ERP with SwiFT study [41] & Prospective/4 centres & $75^{c}$ & $36.5 \pm 11.4$ & $54.9 \pm 14.3$ & $4.4 \pm 3.7$ & NA & $57(76 \%)$ \\
\hline Italian ECMO network [42] & Prospective/14 ICUs & $60 / 153$ & $39(32-46)$ & $63.3(56-79)$ & $2(1-5)$ & $10(7-17)$ & $41(68.3 \%)$ \\
\hline Australian ERP [43] & Retrospective & 38 & NA & 63 & NA & NA & $33(86.8 \%)$ \\
\hline Japanese Society [44] & Retrospective/12 ICUs & 14 & 54 & $50(40-55)$ & $5(0.8-8.5)$ & $8.5(4.0-10.8)$ & $5(35.73 \%)$ \\
\hline $\begin{array}{l}\text { REVA Research Network } \\
\text { in France [45] }\end{array}$ & Prospective/114 ICUs & 123 & $42 \pm 13$ & $63 \pm 21$ & $2(1-5)$ & 9.8 & 79 (64.2\%) \\
\hline Germany ARDS network [46] & $\begin{array}{l}\text { Retrospective/40 } \\
\text { centres }\end{array}$ & $61 / 116$ & $42(39-45)^{d}$ & $87(74-101)^{d}$ & NA & NA & $28(45.9 \%)$ \\
\hline Italian ECMO network [47] & Prospective/14 centres & 60 & $39.7 \pm 12$ & NA & NA & NA & $41(68.3 \%)$ \\
\hline
\end{tabular}

Mean \pm SD or median (interquartile range)

ANZ Australia and New-Zealand, ECMO extracorporeal membrane oxygenation, ERP ECMO Retrieval Program, ICU intensive care unit, MV mechanical ventilation, NA not applicable, pts. patients, SwiFT Swine Flu Triage

a Data before ECMO support

${ }^{\mathrm{b}}$ Discharged alive of patients who underwent ECMO support

${ }^{c}$ Matched pairs among total 80 ECMO referred patients

${ }^{\mathrm{d}}$ Mean values (95\% confidence interval) 
strategy which minimised the alveolar plateau pressure and subsequent pulmonary damage. It was concluded that this minimisation of lung injury was associated with improved outcome compared to conventionally treated patients. No difference in mortality was observed between patients treated with ECMO versus conventional management; however, only $50 \%$ of ECMO patients were successfully matched. A specific subgroup of young patients on ECMO with more favourable outcome remained unmatched. The putative benefits of ECMO are still unproven as the improved outcomes may be caused by patient selection. Davies et al. reported the outcomes of 61 patients with H1N1-associated respiratory failure who were supported with ECMO. The mortality rate was $21 \%$ in the ECMO group compared to those with conventional treatment, highlighting the promising role of ECMO in future outbreaks causing severe respiratory illness [40]. Although a systematic review to inform decisions concerning the use of ECMO in acute respiratory failure during H1N1 pandemic was published, there was insufficient evidence to strongly recommend use of ECMO for patients with H1N1-induced acute respiratory failure [48]. However, it highlighted that in selected patients, ECMO was associated with improved outcome.

\section{Middle East respiratory syndrome}

Another coronavirus, namely the MERS-CoV, originated from Saudi Arabia in 2012 and named Middle East respiratory syndrome (MERS). It resulted in 2494 laboratory-confirmed cases predominantly within the Arabian Peninsula $[49,50]$. As of November 2019, 851 (34\%) confirmed MERS-CoV infections resulted in death. The largest epidemic outbreak outside Saudi Arabia occurred in South Korea in 2015 [51].
Similar to H1N1-induced ARDS, patients with MERS received lung-protective mechanical ventilation and application of early prone positioning with neuromuscular blockade for patients with moderate to severe ARDS ( $\mathrm{PaO} 2: \mathrm{FiO} 2<150 \mathrm{mmHg}$ ) [52]. Approximately 6\% of patients were reported to receive ECMO support as they were unresponsive to conventional treatment [13]. Alshahrani et al. conducted a retrospective chart review on 35 MERS-CoV patients with refractory respiratory failure [14]. Of these, 17 received ECMO and had a lower in-hospital mortality rate than those who received conventional oxygen therapy. We have summarised 6 studies regarding study populations during MERS and ECMO data in Table 3, although we found limited data regarding ECMO use details during MERS outbreak.

\section{ECMO use in ongoing viral outbreak: COVID-19}

ECMO may be considered in patients who develop severe cardiopulmonary failure due to COVID-19 which is refractory to optimal mechanical ventilation and other medical therapies [21]. We have summarised data from recently published clinical reports, ELSO registry report and EuroELSO weekly survey in Table 4 to highlight ECMO use during the COVID-19 pandemic.

During the early outbreak of COVID-19 in China, ECMO was employed for those unresponsive to conventional treatment. Initial reports suggested that ECMO has been used in approximately $3 \%$ of severe cases with restoration of adequate oxygenation [28]. Wang and colleagues described clinical characteristics of 138 hospitalised patients during very early stage of outbreak in Wuhan, China [28] and reported 36 intensive care unit (ICU) admitted patients. Among these, 17 (47\%) required mechanical ventilation and $4(11.1 \%)$ required

Table 3 Demographic data, the patient characteristics and ECMO data of 6 included studies with MERS outbreak (2012-2015)

\begin{tabular}{|c|c|c|c|c|c|c|c|c|c|}
\hline First author & Country & Study design & $\begin{array}{l}\text { Study } \\
\text { population }\end{array}$ & $\begin{array}{l}\text { ECMO pts./ } \\
\text { total pts. }\end{array}$ & $\begin{array}{l}\text { Age of ECMO } \\
\text { pts. (years) }\end{array}$ & $\begin{array}{l}\mathrm{PaO} 2 / \mathrm{FIO}^{\mathrm{a}} \\
(\mathrm{mmHg})\end{array}$ & $\begin{array}{l}\text { MV duration }{ }^{\mathbf{a}} \\
\text { (days) }\end{array}$ & $\begin{array}{l}\text { ECMO duration } \\
\text { (days) }\end{array}$ & $\begin{array}{l}\text { Discharged } \\
\text { alive }^{b}, \boldsymbol{n}(\%)\end{array}$ \\
\hline Choi WS [10] & $\begin{array}{l}\text { South } \\
\text { Korea }\end{array}$ & $\begin{array}{l}\text { Retrospective/ } \\
\text { multicentre }\end{array}$ & Ward and ICU & $13 / 186$ & NA & NA & NA & NA & $8(61.5 \%)$ \\
\hline Rhee JY [11] & & $\begin{array}{l}\text { Case review/ } \\
\text { single centre }\end{array}$ & Ward and ICU & $1 / 5$ & 35 & 53 & $0(4 h)$ & 6 & 0 \\
\hline Al-Dorzi HM [12] & $\begin{array}{l}\text { Saudi } \\
\text { Arabia }\end{array}$ & $\begin{array}{l}\text { Prospective/ } \\
\text { single centre }\end{array}$ & $\mathrm{HCW}$ in ICU & $1 / 8$ & NA & NA & NA & 15 & 0 \\
\hline Arabi YM [13] & & $\begin{array}{l}\text { Retrospective/ } \\
\text { multicentre }\end{array}$ & $\mathrm{ICU}$ & $19 / 330$ & NA & NA & NA & NA & $6(31.6 \%)$ \\
\hline Alshahrani MS [14] & & $\begin{array}{l}\text { Retrospective/ } \\
\text { multicentre }\end{array}$ & $\mathrm{ICU}$ & $17 / 35$ & $45.5(28.5-58.5)$ & NA & NA & NA & $6(35.3 \%)$ \\
\hline Shalhoub S [15] & & $\begin{array}{l}\text { Retrospective/ } \\
\text { multicentre }\end{array}$ & $\begin{array}{l}\mathrm{HCW} \text { in ward } \\
\text { and ICU }\end{array}$ & $9 / 32$ & NA & NA & NA & NA & $4(44.4 \%)$ \\
\hline
\end{tabular}

Mean \pm SD or median (interquartile range)

$H C W$ healthcare worker, ICU intensive care unit admission, $M V$ mechanical ventilation, NA not applicable, pts. patients

a Data before ECMO support

${ }^{b}$ Discharged alive of patients who underwent ECMO support 


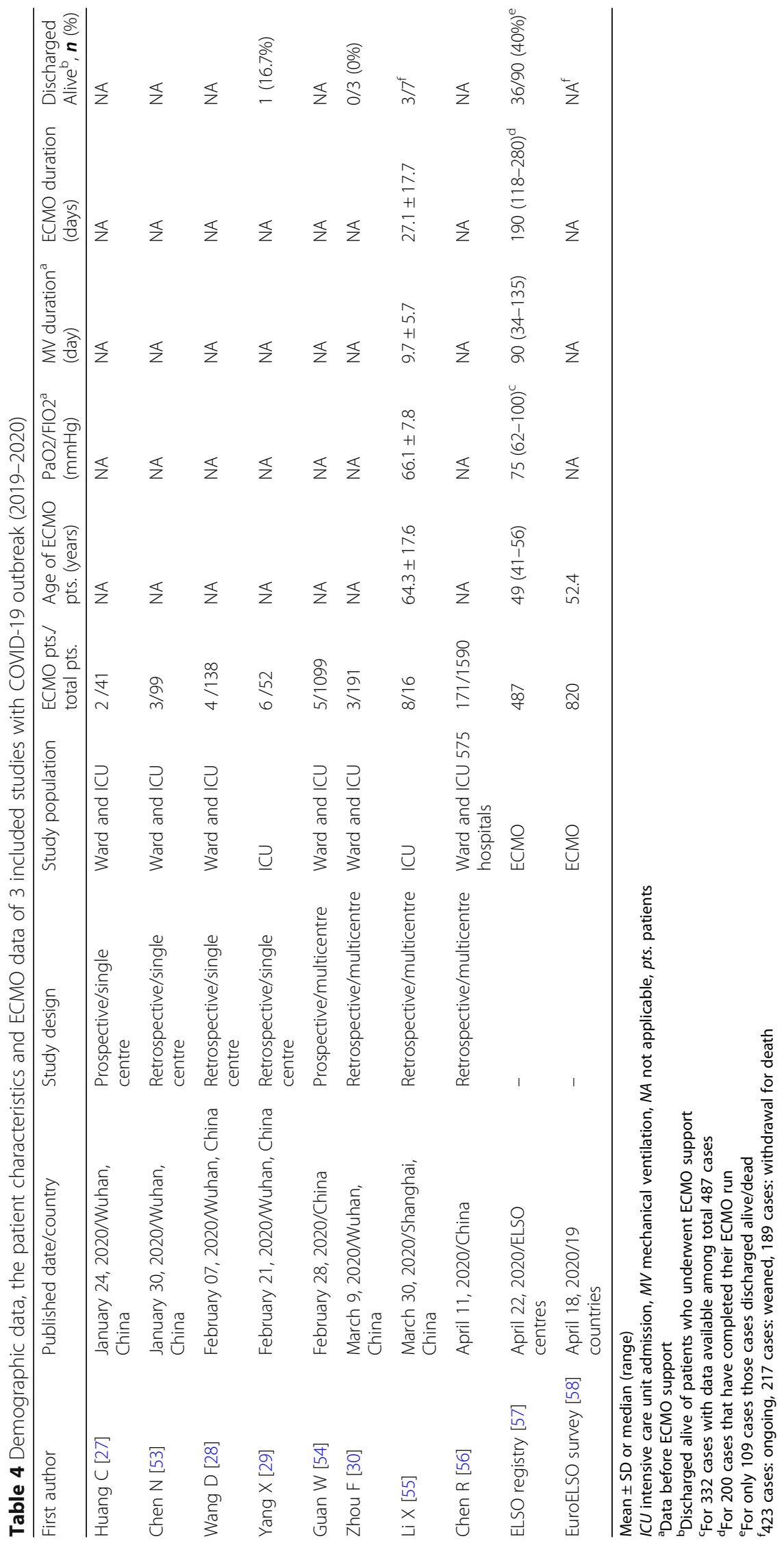


support of ECMO. As of February 3, the overall mortality was $4.3 \%$. There were more nationwide reports from China, and Chen et al. [56] reported 1590 hospitalised patients and 171 ECMO patients but no specific data of ECMO patients were reported yet. Li et al. [55] have reported $16 \mathrm{ICU}$ patients with 8 ECMO patients. Among those 8 patients, 3 patients survived to discharge, 4 died and 1 was still on ECMO.

Additionally, ELSO registry dashboard [57] provides live updates of ECMO use for COVID-19 cases on ECMO (Table 4). As of April 22, the suspected or confirmed cases were 487. Whilst 288 patients (59\%) are still on ECMO, among 90 patients who discharged, 36 patients $(40 \%)$ survived to discharge. ECMO support type was mostly respiratory (95\%), and ECMO mode was mostly V-V (91\%). Furthermore, in $4 \%$ of patients, ECMO was provided via V-A mode for cardiac and extracorporeal cardiopulmonary resuscitation and 3\% had conversion. The EuroELSO survey [58] has now reported ECMO use in over 800 patients as of April 18. Whilst V-V ECMO being the predominant modality used, 423 patients are still on ECMO, 217 patients were weaned from ECMO and 189 ECMO were discontinued due to patients' death. Further data on patient demography, clinical management aspects and outcomes are awaited. Organisations such as the International ECMO Network (www.internationalecmonet.org) will play a significant role in delivering high-quality research in ECMO.

As the COVID-19 pandemic grows, it is essential that we characterise the pathophysiology in those critically ill patients to guide management and optimise outcome. To assist in obtaining as much clinical data as possible from all ICU patients admitted with COVID-19, the COVID-19 Critical Care Consortium Registry was formed in midJanuary 2020 to facilitate data collection, decision support mechanisms through artificial intelligence and a vehicle for future studies regarding ventilation and treatments (ref, unpublished data). Since its initiation to end of March, more than 300 hospitals from 6 continents are participating to characterise critically ill patients and ultimately to reduce their global burden of this disease.

\section{Conclusions}

The experience from previous pandemics has provided preliminary guidance for ECMO use in the current pandemic. The COVID-19 pandemic is unfolding at a time where the better systems for ECMO provision are developed. ECMO is now a well-organised service in many parts of the world; however, inequality remains in terms of access to ECMO. ECMO may not be a therapy that can be extensively used in such pandemic given the resource constraints and availability issues; a responsible use in selected patients is recommended. Although ECMO has a role in critically ill patients, there is currently inadequate data to determine the efficacy, optimal patient selection and management on ECMO. It is essential that we learn and understand throughout the current pandemic, in order determine the risk-benefit ratio of ECMO in COVID-19.

\begin{abstract}
Abbreviations
ARDS: Acute respiratory distress syndrome; CESAR: Conventional Ventilation or ECMO for Severe Adult Respiratory failure; COVID-19: Coronavirus disease 2019; ECMO: Extracorporeal membrane oxygenation; ELSO: Extracorporeal Life Support Organization; FIO2: Fraction of inspired oxygen; ICU: Intensive care unit; MERS: Middle East respiratory syndrome; PaO2: Partial pressure of oxygen in arterial blood; SARS: Severe acute respiratory syndrome; SARSCoV: Severe acute respiratory syndrome coronavirus; SARS-CoV-2: Severe acute respiratory syndrome coronavirus 2; WHO: World Health Organization
\end{abstract}

\section{Acknowledgements}

JYS acknowledges the support of AQIRF by the Queensland Government. KS acknowledges research support from Metro North Hospital and Health Service.

\section{Authors' contributions}

$\mathrm{HJC}$ and JFF constructed this review. HJC and SH wrote the initial manuscript. HJC was a major contributor in writing the manuscript. KS and ISJ critically evaluated the manuscript and made substantial contributions to the writing and editing of the manuscript. All authors revised the initial manuscript and approved its final version.

\section{Funding}

HJC acknowledges the support of a grant NRF-2018R1D1A1A02085975 from the National Research Foundation of Korea and a grant BCRI18028 from the Chonnam National University Hospital Biomedical Research Institute.

Availability of data and materials

Not applicable

Ethics approval and consent to participate

Not applicable

Consent for publication

Not applicable

\section{Competing interests}

The authors declare that they have no competing interests.

\section{Author details}

${ }^{1}$ Critical Care Research Group, Faculty of Medicine, University of Queensland and The Prince Charles Hospital, Brisbane, Australia. ${ }^{2}$ Department of Pediatrics, Chonnam National University Children's Hospital and Medical School, Gwangju, Republic of Korea. ${ }^{3}$ Department of Thoracic and Cardiovascular Surgery, Chonnam National University Hospital and Medical School, Gwangju, Republic of Korea. ${ }^{4}$ Adult Intensive Care Services, The Prince Charles Hospital, Brisbane, Australia. ${ }^{5}$ Institut d'Investigacions Biomediques August Pi i Sunyer, Barcelona, Spain. ${ }^{6}$ Department of Thoracic and Cardiovascular Surgery, College of Medicine, Korea University, Seoul, Republic of Korea.

Received: 28 April 2020 Accepted: 12 May 2020

Published online: 06 June 2020

\section{References}

1. WHO Director-General's opening remarks at the media briefing on COVID19. https://www.who.int/dg/speeches/detail/who-director-general-sopening-remarks-at-the-media-briefing-on-covid-19\%2D\%2D-11-march-202 0. Accessed 22 Apr 2020.

2. Coronavirus (COVID-19) World Health Organization Overview. https://covid1 9.who.int/. Accessed 22 Apr 2020

3. Peiris JS, Yuen KY, Osterhaus AD, Stohr K. The severe acute respiratory syndrome. N Engl J Med. 2003;349(25):2431-41. 
4. Lee N, Hui D, Wu A, Chan P, Cameron P, Joynt GM, Ahuja A, Yung MY, Leung $C B$, To KF, et al. A major outbreak of severe acute respiratory syndrome in Hong Kong. N Engl J Med. 2003;348(20):1986-94.

5. Varia M, Wilson S, Sarwal S, McGeer A, Gournis E, Galanis E, Henry B, Hospital Outbreak Investigation T: Investigation of a nosocomial outbreak of severe acute respiratory syndrome (SARS) in Toronto, Canada CMAJ 2003, 169(4):285-292.

6. Donnelly CA, Ghani AC, Leung GM, Hedley AJ, Fraser C, Riley S, Abu-Raddad U, Ho LM, Thach TQ, Chau P, et al. Epidemiological determinants of spread of causal agent of severe acute respiratory syndrome in Hong Kong. Lancet. 2003;361(9371):1761-6.

7. Riley S, Fraser C, Donnelly CA, Ghani AC, Abu-Raddad LJ, Hedley AJ, Leung GM, Ho LM, Lam TH, Thach TQ, et al. Transmission dynamics of the etiological agent of SARS in Hong Kong: impact of public health interventions. Science. 2003;300(5627):1961-6.

8. Lipsitch M, Cohen T, Cooper B, Robins JM, Ma S, James L, Gopalakrishna G, Chew SK, Tan CC, Samore MH, et al. Transmission dynamics and control of severe acute respiratory syndrome. Science. 2003;300(5627):1966-70.

9. Fowler RA, Lapinsky SE, Hallett D, Detsky AS, Sibbald WJ, Slutsky AS, Stewart TE, Group ftTSCC: Critically ill patients with severe acute respiratory syndrome. JAMA 2003, 290(3):367-373.

10. Choi WS, Kang Cl, Kim Y, Choi JP, Joh JS, Shin HS, Kim G, Peck KR, Chung $\mathrm{DR}$, Kim HO , et al. Clinical presentation and outcomes of Middle East respiratory syndrome in the Republic of Korea. Infection Chemotherapy. 2016:48(2):118-26.

11. Rhee JY, Hong G, Ryu KM. Clinical implications of 5 cases of Middle East respiratory syndrome coronavirus infection in a South Korean outbreak. Jpn J Infect Dis. 2016;69(5):361-6.

12. Al-Dorzi HM, Aldawood AS, Khan R, Baharoon S, Alchin JD, Matroud AA, Al Johany SM, Balkhy HH, Arabi YM. The critical care response to a hospital outbreak of Middle East respiratory syndrome coronavirus (MERS-CoV) infection: an observational study. Ann Intensive Care. 2016;6(1):101.

13. Arabi YM, Al-Omari A, Mandourah Y, Al-Hameed F, Sindi AA, Alraddadi B, Shalhoub S, Almotairi A, Al Khatib K, Abdulmomen A, et al. Critically ill patients with the Middle East respiratory syndrome: a multicenter retrospective cohort study. Crit Care Med. 2017:45(10):1683-95.

14. Alshahrani MS, Sindi A, Alshamsi F, Al-Omari A, El Tahan M, Alahmadi B, Zein A, Khatani N, Al-Hameed F, Alamri S, et al. Extracorporeal membrane oxygenation for severe Middle East respiratory syndrome coronavirus. Ann Intensive Care. 2018;8(1):3.

15. Shalhoub S, Al-Hameed F, Mandourah Y, Balkhy HH, Al-Omari A, Al Mekhlafi GA, Kharaba A, Alraddadi B, Almotairi A, Al Khatib K, et al. Critically ill healthcare workers with the Middle East respiratory syndrome (MERS): a multicenter study. PLoS One. 2018;13(11):e0206831.

16. Peek GJ, Mugford M, Tiruvoipati R, Wilson A, Allen E, Thalanany MM, Hibbert $\mathrm{CL}$, Truesdale A, Clemens F, Cooper N, et al. Efficacy and economic assessment of conventional ventilatory support versus extracorporeal membrane oxygenation for severe adult respiratory failure (CESAR): a multicentre randomised controlled trial. Lancet (London, England). 2009; 374(9698):1351-63.

17. Goligher EC, Tomlinson G, Hajage D, Wijeysundera DN, Fan E, Jüni P, Brodie D, Slutsky AS, Combes A. Extracorporeal membrane oxygenation for severe acute respiratory distress syndrome and posterior probability of mortality benefit in a post hoc Bayesian analysis of a randomized clinical trial. Jama. 2018;320(21):2251-9

18. Sukhal S, Sethi J, Ganesh M, Villablanca PA, Malhotra AK, Ramakrishna H. Extracorporeal membrane oxygenation in severe influenza infection with respiratory failure: a systematic review and meta-analysis. Ann Card Anaesth. 2017;20(1):14-21.

19. Aretha D, Fligou F, Kiekkas P, Karamouzos V, Voyagis G. Extracorporeal life support: the next step in moderate to severe ARDS-a review and metaanalysis of the literature. Biomed Res Int. 2019;2019:1035730.

20. Combes A, Hajage D, Capellier G, Demoule A, Lavoué S, Guervilly C, Da Silva $D$, Zafrani $L$, Tirot $P$, Veber $B$, et al. Extracorporeal membrane oxygenation for severe acute respiratory distress syndrome. N Engl J Med. 2018;378(21): 1965-75.

21. MacLaren G, Fisher D, Brodie D. Preparing for the most critically ill patients with COVID-19: the potential role of extracorporeal membrane oxygenation Jama. 2020. https://doi.org/10.1001/jama.2020.2342. [Epub ahead of print].

22. Dawood FS, luliano AD, Reed C, Meltzer MI, Shay DK, Cheng PY, Bandaranayake D, Breiman RF, Brooks WA, Buchy P, et al. Estimated global mortality associated with the first 12 months of 2009 pandemic influenza A H1N1 virus circulation: a modelling study. Lancet Infect Dis. 2012;12(9):68795

23. Ukimura A, Satomi H, Ooi Y, Kanzaki Y. Myocarditis associated with influenza A H1N1pdm2009. Influenza Res Treat. 2012;2012:351979.

24. Zaki AM, van Boheemen S, Bestebroer TM, Osterhaus AD, Fouchier RA. Isolation of a novel coronavirus from a man with pneumonia in Saudi Arabia. N Engl J Med. 2012;367(19):1814-20.

25. Assiri A, McGeer A, Perl TM, Price CS, Al Rabeeah AA, Cummings DA, Alabdullatif ZN, Assad M, Almulhim A, Makhdoom H, et al. Hospital outbreak of Middle East respiratory syndrome coronavirus. N Engl J Med. 2013;369(5): 407-16.

26. Arabi YM, Arifi AA, Balkhy HH, Najm H, Aldawood AS, Ghabashi A, Hawa H, Alothman A, Khaldi A, Al Raiy B. Clinical course and outcomes of critically ill patients with Middle East respiratory syndrome coronavirus infection. Ann Intern Med. 2014;160(6):389-97.

27. Huang C, Wang Y, Li X, Ren L, Zhao J, Hu Y, Zhang L, Fan G, Xu J, Gu X, et al. Clinical features of patients infected with 2019 novel coronavirus in Wuhan, China. Lancet (London, England). 2020;395(10223):497-506.

28. Wang D, Hu B, Hu C, Zhu F, Liu X, Zhang J, Wang B, Xiang H, Cheng Z, Xiong $Y$, et al. Clinical characteristics of 138 hospitalized patients with 2019 novel coronavirus-infected pneumonia in Wuhan, China. JAMA. 2020; 323(11):1061-9.

29. Yang $X, Y u$ Y, Xu J, Shu $H$, Xia J, Liu H, Wu Y, Zhang L, Yu Z, Fang M, et al. Clinical course and outcomes of critically ill patients with SARS-CoV-2 pneumonia in Wuhan, China: a single-centered, retrospective, observational study. Lancet Respir Med. 2020;8(5):475-81. https://doi.org/10.1016/S22132600(20)30079-5.

30. Zhou F, Yu T, Du R, Fan G, Liu Y, Liu Z, Xiang J, Wang Y, Song B, Gu X, et al. Clinical course and risk factors for mortality of adult inpatients with COVID19 in Wuhan, China: a retrospective cohort study. Lancet (London, England). 2020;395(10229):1054-62.

31. Xie $Y$, Wang $X$, Yang P, Zhang S. COVID-19 complicated by acute pulmonary embolism. Radiology: Cardiothoracic Imaging. 2020;2(2):e200067.

32. Varga Z, Flammer AJ, Steiger $P$, Haberecker M, Andermatt $R$, Zinkernagel AS, Mehra MR, Schuepbach RA, Ruschitzka F, Moch H. Endothelial cell infection and endotheliitis in COVID-19. Lancet. 2020;395(10234):1417-18. https://doi. org/10.1016/S0140-6736(20)30937-5.

33. Hua A, O'Gallagher K, Sado D, Byrne J. Life-threatening cardiac tamponade complicating myo-pericarditis in COVID-19. Eur Heart J. 2020. https://doi. org/10.1093/eurheartj/ehaa253. [Epub ahead of print].

34. Inciardi RM, Lupi L, Zaccone G, Italia L, Raffo M, Tomasoni D, Cani DS, Cerini M, Farina D, Gavazzi E, et al. Cardiac involvement in a patient with coronavirus disease 2019 (COVID-19). JAMA Cardiol. 2020. https://doi.org/10. 1001/jamacardio.2020.1096. [Epub ahead of print].

35. Ruan Q, Yang K, Wang W, Jiang L, Song J: Clinical predictors of mortality due to COVID-19 based on an analysis of data of 150 patients from Wuhan, China. Intensive Care Med. 2020;46(5):846-48. https://doi.org/10.1007/ s00134-020-05991-x.

36. Extracorporeal Life Support Organization COVID-19 Interim Guidelines. https://www.elso.org/Portals/0/Files/pdf/ELSO\%20covid\%20guidelines\%2 Ofinal.pdf. Accessed 22 Apr 2020.

37. Perez-Padilla $R$, de la Rosa-Zamboni D, Ponce de Leon $S$, Hernandez M, Quinones-Falconi F, Bautista E, Ramirez-Venegas A, Rojas-Serrano J, Ormsby $\mathrm{CE}$, Corrales $\mathrm{A}$, et al. Pneumonia and respiratory failure from swine-origin influenza A (H1N1) in Mexico. N Engl J Med. 2009;361(7):680-9.

38. Echevarria-Zuno S, Mejia-Arangure JM, Mar-Obeso AJ, Grajales-Muniz C, RoblesPerez E, Gonzalez-Leon M, Ortega-Alvarez MC, Gonzalez-Bonilla C, RasconPacheco RA, Borja-Aburto VH. Infection and death from influenza A H1N1 virus in Mexico: a retrospective analysis. Lancet. 2009;374(9707):2072-9.

39. Bautista E, Chotpitayasunondh T, Gao Z, Harper SA, Shaw M, Uyeki TM, Zaki SR, Hayden FG, Hui DS, Kettner JD, et al. Clinical aspects of pandemic 2009 influenza A (H1N1) virus infection. N Engl J Med. 2010;362(18):1708-19.

40. Australia, New Zealand Extracorporeal Membrane Oxygenation Influenza I, Davies A, Jones D, Bailey M, Beca J, Bellomo R, Blackwell N, Forrest P, Gattas D, et al. Extracorporeal membrane oxygenation for 2009 influenza A(H1N1) acute respiratory distress syndrome. JAMA. 2009;302(17):1888-95.

41. Noah MA, Peek GJ, Finney SJ, Griffiths MJ, Harrison DA, Grieve R, Sadique MZ, Sekhon JS, McAuley DF, Firmin RK, et al. Referral to an extracorporeal membrane oxygenation center and mortality among patients with severe 2009 influenza A(H1N1). Jama. 2011;306(15):1659-68. 
42. Patroniti N, Zangrillo A, Pappalardo F, Peris A, Cianchi G, Braschi A, lotti GA, Arcadipane A, Panarello G, Ranieri VM, et al. The Italian ECMO network experience during the 2009 influenza $\mathrm{A}(\mathrm{H} 1 \mathrm{~N} 1)$ pandemic: preparation for severe respiratory emergency outbreaks. Intensive Care Med. 2011;37(9): 1447-57.

43. Forrest $P$, Ratchford J, Burns $B$, Herkes $R$, Jackson A, Plunkett B, Torzillo $P$, Nair $P$, Granger $E$, Wilson $M$, et al. Retrieval of critically ill adults using extracorporeal membrane oxygenation: an Australian experience. Intensive Care Med. 2011;37(5):824-30.

44. Takeda S, Kotani T, Nakagawa S, Ichiba S, Aokage T, Ochiai R, Taenaka N, Kawamae K, Nishimura M, Ujike Y, et al. Extracorporeal membrane oxygenation for 2009 influenza $A(H 1 N 1)$ severe respiratory failure in Japan. J Anesth. 2012;26(5):650-7.

45. Pham T, Combes A, Rozé H, Chevret S, Mercat A, Roch A, Mourvillier B, AraSomohano C, Bastien O, Zogheib E, et al. Extracorporeal membrane oxygenation for pandemic influenza $\mathrm{A}(\mathrm{H} 1 \mathrm{~N} 1)$-induced acute respiratory distress syndrome: a cohort study and propensity-matched analysis. Am J Respir Crit Care Med. 2013;187(3):276-85.

46. Weber-Carstens S, Goldmann A, Quintel M, Kalenka A, Kluge S, Peters J, Putensen C, Müller T, Rosseau S, Zwißler B, et al. Extracorporeal lung support in H1N1 provoked acute respiratory failure: the experience of the German ARDS Network. Deutsches Arzteblatt Int. 2013;1 10(33-34):543-9.

47. Pappalardo F, Pieri M, Greco T, Patroniti N, Pesenti A, Arcadipane A, Ranieri VM, Gattinoni L, Landoni G, Holzgraefe B, et al. Predicting mortality risk in patients undergoing venovenous ECMO for ARDS due to influenza A ( $\mathrm{H} 1 \mathrm{~N} 1)$ pneumonia: the ECMOnet score Intensive Care Med. 2013:39(2):275-81.

48. Mitchell MD, Mikkelsen ME, Umscheid CA, Lee I, Fuchs BD, Halpern SD. A systematic review to inform institutional decisions about the use of extracorporeal membrane oxygenation during the H1N1 influenza pandemic. Crit Care Med. 2010;38(6):1398-404.

49. Arabi YM, Balkhy HH, Hayden FG, Bouchama A, Luke T, Baillie JK, Al-Omari A, Hajeer AH, Senga M, Denison MR, et al. Middle East respiratory syndrome. N Engl J Med. 2017;376(6):584-94.

50. World Health Organization: MERS Situation Update November 2019. https:// www.who.int/emergencies/mers-cov/en/. Accessed 22 Apr 2020.

51. Oh MD, Park WB, Park SW, Choe PG, Bang JH, Song KH, Kim ES, Kim HB, Kim NJ. Middle East respiratory syndrome: what we learned from the 2015 outbreak in the Republic of Korea. Korean J Intern Med. 2018;33(2):233-46.

52. Al-Dorzi HM, Alsolamy S, Arabi YM. Critically ill patients with Middle East respiratory syndrome coronavirus infection. Crit Care. 2016;20(1):65.

53. Chen N, Zhou M, Dong X, Qu J, Gong F, Han Y, Qiu Y, Wang J, Liu Y, Wei Y, et al. Epidemiological and clinical characteristics of 99 cases of 2019 Novel coronavirus pneumonia in Wuhan, China: a descriptive study. Lancet (London, England) 2020. 395(10223):507-13.

54. Guan WJ, Ni ZY, Hu Y, Liang WH, Ou CQ, He JX, Liu L, Shan H, Lei CL, Hui DSC, et al. Clinical characteristics of coronavirus disease 2019 in China. N Engl J Med. 2020;382(18):1708-20. https://doi.org/10.1056/NEJMoa2002032.

55. Li X, Guo Z, Li B, Zhang X, Tian R, Wu W, Zhang Z, Lu Y, Chen N, Clifford SP et al: Extracorporeal membrane oxygenation for coronavirus disease 2019 in Shanghai, China. ASAIO J 2020;66(5):475-81. https://doi.org/10.1097/MAT. 0000000000001172.

56. Chen R, Liang W, Jiang M, Guan W, Zhan C, Wang T, Tang C, Sang L, Liu J, $\mathrm{Ni}$ Z, et al. Risk factors of fatal outcome in hospitalized subjects with coronavirus disease 2019 from a nationwide analysis in China. Chest. 2020. https://doi.org/10.1016/j.chest.2020.04.010. [Epub ahead of print].

57. ELSO COVID-19 Registry Dashboard. https://www.elso.org/Registry/ FullCOVID19RegistryDashboard.aspx. Accessed 22 Apr 2020.

58. EuroELSO Survey on ECMO use in Adult COVID-19 Patients in Europe. https://www.euroelso.net/covid-19/covid-19-survey/. Accessed 22 Apr 2020.

\section{Publisher's Note}

Springer Nature remains neutral with regard to jurisdictional claims in published maps and institutional affiliations. 